\title{
Peran Petugas Lingkungan Pondok Sosial (Liposos) dalam Pengelolaan Diapers pada Klien di UPTD. Liposos Jember
}

\section{Role of Social Shelter Officer in Diapers Management of its Clients at the Jember Social Shelter}

\author{
Ghaniu Putri Habsari, Dewi Rokhmah, Iken Nafikadini \\ Fakultas Kesehatan Masyarakat Universitas Jember \\ e-mail korespondensi: ghaniyuputrihabsari215@gmail.com
}

\begin{abstract}
Diapers are devices in highly absorbent disposable diapers made of plastic and a mixture of chemicals to accommodate metabolic waste such as urine and feces. Diapers are included in hazardous and toxic waste materials called B3 waste. B3 waste is the residue of a business or activity containing B3. The use of adult diapers in the elderly and people with mental disorders who are unconscious and experiencing physical impairment is widely used as an alternative to urinary control. As many as $42.3 \%$ of people hospitalized with decreased mobility, physical ability, and distress use adult diapers as an alternative to urinary control in the treatment process. This was a quantitative study aimed to analyze the role of social shelter (UPTD. LIPOSOS) officer in managing diapers for mental disorders clients at the social shelter, Jember. There were 5 respondents. The result showed that diapers were managed by hoarding, burial, and burning. The selection of diapers is inappropriate in terms of the size and brand. It can be concluded that diapers management at the social shelter (UPTD. LIPOSOS), Jember had not proper and correct yet and need to be optimize.
\end{abstract}

Keywords: Strategy, Management, Diapers

\begin{abstract}
Abstrak
Diapers merupakan alat yang berupa popok sekali pakai berdaya serap tinggi yang terbuat dari plastik dan campuran bahan kimia untuk menampung sisa-sisa metabolisme seperti air seni dan feses. Diapres masuk dalam limbah bahan berbahaya dan beracun yang disebut limbah B3. Limbah B3 adalah sisa suatu usaha atau kegiatan yang mengandung B3. Penggunaan diapers dewasa pada orang tua dan orang dengan gangguan jiwa yang tidak memiliki kesadaran dan mengalami pelemahan fisik banyak digunakan sebagai alternatif kontrol kemih, sebanyak $42,3 \%$ orang yang dirawat dirumah sakit yang mengalami penurunan mobilitas, kemampuan fisik dan kesadaan menggunakan diapers dewasa sebagai alternatif kontrol kemih dalam proses perawatan. Penelitian ini merupakan penelitian kuantitatif yang bertujuan untuk menganalisis peran petugas lingkungan pondok sosial (LIPOSOS) dalam pengelolaan diapers pada klien ODGJ di UPTD LIPOSOS. Ada lima responden yang berpartisipasi dalam penelitian. Hasil penelitian menunjukkan bahwa pengelolaan diapers dilakukan dengan cara penimbunan, penguburan dan pembakaran. Pemilihan diapers kurang memadai terkait dengan ukuran dan merk yang digunakan. Dapat disimpulkan bahwa belum ada pengelolalan secara baik dan benar mengenai pengolahan diapers di UPTD. LIPOSOS, Jember.
\end{abstract}

Kata Kunci : Peran, Pengelolaan, Diapers 


\section{Pendahuluan}

Kesehatan adalah keadaan sehat baik secara fisik, mental, spiritual, maupun sosial yang memungkinkan setiap orang untuk hidup produktif secara sosial dan ekonomis. Sedangkan kondisi dimana berkembangnya seorang individu secara fisik mental dan spiritual hingga sosial serta dapat menyadari kemampuan sendiri dapat mengatasi tekanan dan dapat bekerja secara produktif merupakan definisi dari kesehatan jiwa [1].

Menurut Fioda dalam (Tumanduk et al, 2018:12) kondisi gangguan mental pada seseorang dapat mempengaruhi kemampuan individu dalam melakukan aktivitas sehari-hari seperti merawat diri, mandi, berpakaian, merapikan rambut dan sebagainya serta berkurangnya kemampuan dan kemauan untuk memenuhi kebutuhan dasarnya seperti tidak mau makan, minum, sedikitnya gerakan yang dilakukan, tidak mau buang air kecil dan buang air besar. Oleh karena itu, pasien ODGJ umumnya membutuhkan diapers dalam kesehariannya [2].

Klien dengan gangguan jiwa membutuhkan perawatan diri yang lebih besar daripada kemampuannya sendiri dalam merawat diri. Penggunaan diapers dewasa pada orang tua dan orang dengan gangguan jiwa yang tidak memiliki kesadaran dan mengalami pelemahan fisik banyak digunakan sebagai alternatif kontrol kemih, sebanyak $42,3 \%$ orang yang dirawat dirumah sakit yang mengalami penurunan mobilitas, kemampuan fisik dan kesadaan menggunakan diapers dewasa sebagai alternatif kontrol kemih dalam proses perawatan.

Penggunaan diapers sembarangan tanpa memerhatikan ukuran bahan dan personal hygiene dapat menghasilkan dampak buruk pada pengguna dampak buruk dapat disebabkan karena perubahan oleh kombinasi faktor urin dan tinja, kelembapan, waktu berkepanjangan kontak dengan urin dan tinja, gesekan dan tekanan pada kulit saat penggunaan diapers.

Diapres masuk dalam limbah bahan berbahaya dan beracun yang disebut limbah B3. Limbah B3 adalah sisa suatu usaha atau kegiatan yang mengandung B3 [3].

Penggunaan diapers yang semakin besar dan peningkatan jumlah sampah diapers disebabkan oleh sifat bahan pada diapers yang $55 \%$ terbuat dari plastik, karena terbuat dari bahan plastik diapers tidak mudah terurai atau terdegradasi hal tersebut membuat sampah diapers semakin meningkat selain itu zat kimia yang ada pada diapers memiliki sifat tidak mudah terurai sehingga dapat mencemari lingkungan.

Peran petugas lingkungan LIPOSOS dalam menerapkan personal hygiene terkait penggunaan diapers pada ODGJ umumnya dipengaruhi oleh berbagai hal. Pengetahuan dan sikap dapat mempengaruhi perilaku, namun tidak selamanya hubungan tersebut berbanding lurus. Masih terdapat potensi bahwa akan terjadi hubungan yang tidak dapat diprediksi [4]. Secara teori perubahan perilaku terdapat tiga komponen didalamnya yaitu pengetahuan, sikap, dan tindakan [5]. Tujuan penelitian ini adalah menganalisis terhadap peran petugas lingkungan pondok sosial (LIPOSOS) dalam pengelolaan diapers pada klien ODGJ di UPTD. LIPOSOS Kabupaten Jember.

\section{Metode Penelitian}

Jenis penelitian ini merupakan penelitian deskriptif dengan pendekatan kuantitatif, desain yang digunakan adalah studi kasus. Penentuan informan dalam penelitian ini adalah dengan menggunakan teknik purposive. Teknik pengumpulan data yaitu berupa wawancara mendalam, observasi dan dokumentasi.

Data variabel penelitian berupa in-depth interview, observasi non partisipatif, dan instrumen pengumpulan data. Teknik analisis data dalam penelitian ini dilakukan menggunakan analisis interaktif.

\section{Hasil Penelitian}

\section{a. Karakteristik responden}

Karakteristik responden dalam penelitian ini meliputi jenis kelamin, usia, pendidikan, pekerjaan, lama bekerja, dan tempat asal. Distribusi akan diuraikan sebagai berikut:

Jenis kelamin responden sebagi informan utama dalam penelitian ini terdiri dari laki-laki dan perempuan, sesuai table 1 berikut.

\begin{tabular}{ccccccc}
\multicolumn{5}{c}{ Tabel 1. Distribusi jenis kelamin dari responden } \\
\hline Informan & Usia & $\begin{array}{c}\text { Jenis } \\
\text { kelamin }\end{array}$ & Pendidikan & $\begin{array}{c}\text { Status } \\
\text { pekerjan }\end{array}$ & $\begin{array}{c}\text { Lama } \\
\text { bekerja }\end{array}$ & $\begin{array}{c}\text { Tempat } \\
\text { asal }\end{array}$ \\
\hline SS & $\begin{array}{c}35 \\
\text { tahun }\end{array}$ & Perempuan & D3 & $\begin{array}{c}\text { Pekerja sosial } \\
\text { (staf) }\end{array}$ & 7 tahun & Jember \\
M & $\begin{array}{c}42 \\
\text { tahun }\end{array}$ & Laki-laki & SMA & $\begin{array}{c}\text { Pekeja sosial } \\
\text { (staf) }\end{array}$ & 3 bulan & Jember \\
EB & $\begin{array}{c}33 \\
\text { tahun }\end{array}$ & Laki-laki & SMA & $\begin{array}{c}\text { Pekeja sosial } \\
\text { (staf) }\end{array}$ & 10 tahun & Jember \\
AS & 36 & Laki-laki & S1 & $\begin{array}{c}\text { Pekerja sosial } \\
\text { (staf) }\end{array}$ & 10 tahun & Jember \\
\hline
\end{tabular}


Berdasarkan tabel 1 dapat diketahui bahwa rerata staf di UPTD. LIPOSOS berjenis kelamin laki-laki dan berasal dari Jember. Rerata jenjang pendidikan staf UPTD. LIPOSO yakni SMA, D3 dan S1 dan berusia kurang dari 50 tahun.

Selain itu juga ada responden sebagai informan tambahan, dengan karakteristik sebagai berikut; berjenis kelamin laki- laki, berusia 35 tahun status pendidikan $\mathrm{S} 1$, berasal dari Jember dan status pekerjaan sebagai Koordinator Pengelola UPTD. LIPOSOS.

\section{Pembahasan}

Peran Koordinator terhadap Fasilitator Sarana dan Prasarana di UPTD. LIPOSOS Dari Hasil penelitian, peneliti menemukan beberapa peran koordinator dalam penanganan sarana dan prasarana di UPTD. Liposos, yaitu sebagai fasilitator, penyedia sarana dan prasarana, pengawasan pekerja, penyedia pelatihan, serta pembagian petugas dan pengawasan. Informasi yang ingin diketahui oleh peneliti adalah bagaimana ketersediaan sarana dan prasarana di UPTD.LIPOSOS Jember.

Berdasarkan hasil wawancara yang dilakukan dengan Informan Kunci (RE, 40 tahun) menyatakan bahwa sarana dan prasarana di UPTD. LIPOSOS cukup memadai. Koordinator memiliki pengetahuan yang baik mengenai pengelolaan diapers. Pengetahuan yang dimaksud dalam penelitian ini yaitu pengetahun tentang diapers dan pengolahan limbah diapers oleh koordinator dan pekerja UPTD. LIPOSOS. Pengawasan terhadap klien dilakukan selama 24 jam untuk memenuhi kebutuhan dari klien di UPTD. LIPOSOS. Pengawasan terhadap klien yang dilakukan meliputi seluruh kegiatan seharihari termasuk makan, mandi, dan kontrol kesehatan.

Petugas UPTD. LIPOSOS umumnya diberi pelatihan dari dinas sosial terkait pelatihan dasar setiap tahunnya. Pelatihan ini akan membantu petugas dalam menjalankan tugasnya di UPTD. LIPOSOS. Sedangkan untu pelaporan petugas UPTD. LIPOSOS kepada Dinas Sosial Kabupaten Jember dilakukan setiap hari dengan melaporkan jumlah klien keluar, jumlah klien masuk, dan jumlah klien yang kabur setiap harinya.

\section{Personal Hygiene Pekerja Sosial dalam Mengelola Diapers \\ Cara pengolahan diapers di UPTD.} LIPOSOS yaitu dengan cara dibakar, hanya beberapa diapers yang masih terdapat kotoran perlu dibuang di tempat khusus sebelum dibakar. Perlakuan ini digunakan karena diapers yang telah digunakan klien tidak dicuci terlebih dahulu sehingga diapers masih kotor dan basah. Hal ini menyebabkan diapers tidak dapat langsung dibakar. Hal ini sesuai pernyataan dari informan SS yang menyatakan bahwa terdapat tempat tersendiri sebagai pembuangannya sebelum dibakar.

Semua informan utama menyatakan pengelolaan limbah diapers di UPTD. LIPOSOS lebih sering dibakar dari pada di kubur hal ini dikarenakan tidak ada lahan untuk mengubur limbah diapers tersebut. Koordinator UPTD. LIPOSOS menyadari bahwa seharusnya dan alangkah lebih baiknya jika limbah diapers tersebut dapat di daur ulang.

Diapers belum dapat didaur ulang karena belum ada yang dapat mengelola dan masih jijik terhadap kotoran dari diapersnya sehingga untuk pendaurulangan belum dapat dilakukan. Sebenanrnya, diapers dapat di daur ulang karena mengandung material plastik. Material sampah yang dapat di daur ulang meliputi kertas, kaca, plastik, kayu, aluminium dan besi [6].

$$
\text { Keuntungan daur ulang yaitu }
$$

mengurangi jumlah sampah yang ditimbun di TPA dan insinerasi, polusi dengan mengurangi penggunaan bahan mentah, mengurangi emisi gas rumah kaca yang berkontribusi dibandingkan dengan pembakaran, serta memperpanjang usia lingkungan di masa depan. Menurut penelitian Ali (2017:7), daur ulang diapers kotor dilakukan untuk mendapatkan kembali serat dan plastik yang berharga termasuk mengumpulkan popok kotor, mengangkutnya ke pabrik perawatan di mana popok tersebut dibuka, disterilkan, SAP dinonaktifkan, diparut dan dipisahkan menjadi fraksi yang dapat didaur ulang (bubur halus, SAP, plastik dan bahan organik) [7].

Hasil penelitian ini menunjukkan bahwa pengelolaan diapers oleh staf di UPTD. LIPOSOS belum sesuai dengan pengelolaan limbah diapers yang benar. Terdapat beberapa 
hal yang tidak dilakukan dalam pengelolaan diapers yang baik di UPTD. LIPOSOS yaitu sampah diapers tidak dibersihkan terlebih dahulu sebelum dibakar dan sampah diapers tidak dipisahkan dengan sampah rumah tangga lainnya. Menurut penelitian Ali (2017:48), diapers dapat menyebabkan kontaminasi permukaan tanah dan air karena mengandung kotoran yang akan meningkatkan ancaman virus dan bakteri masuk ke air permukaan dan air tanah. Tinja mengandung bakteri dan virus, 1 gram tinja mengandung 1 milyar virus infektif. Bakteri yang selalu ada dalam tinja manusia antara lain Bacterioides fragillus, Fecal coliform, Escherchia coli, Fecla streptococci dan Enterococci. Sebelum dibuang ke lingkungan, popok harus di bersihkan terlebih dulu terutama popok yang masih mengandung tinja dan tinja harus dibuang ke kloset terlebih dulu [3]. Diapres juga termasuk dalam limbah bahan berbahaya dan beracun yang disebut limbah B3. Pengelolaan sampah diapers seharusnya dipisahkan dengan sampah rumah tangga lain, hal ini dikarenakan sampah B3 mengandung bahan berbahaya dan atau beracun, karena sifat atau konsentrasinya dan atau jumlahnya, baik secara langsung maupun tidak langsung dapat merusak dan atau mencemarkan lingkungan hidup dan atau membahayakan kesehatan manusia (SNI 192454-2002).

\section{Simpulan dan Saran}

Dari lima responden penelitian inii yang terdiri dari 4 orang laki- laki dan 1 orang perempuan dengan pendidikan yang beragam, mulai dari SMA, D3, dan S1 serta lama bekerja cukup beragam, mulai dari 3 bulan, 7 tahun, 2 dan 10 tahun, diketahui bahwa belum ada pengelolalan secara baik dan benar mengenai pengolahan diapers. Selain itu, pemilihan diapers sesuai dengan ukuran dan merk tidak dapat dilakukan karena hanya mendapatkan dari dinas sosial terkait.

Perlu strategi meningkatkan pengetahuan petugas terkait manajemen pengelolaan diapers yang baik dan benar agar dapat dilaksankan dengan optimal.

\section{Ucapan Terima Kasih}

Peneliti mengucapkan terima kasih yang begitu besar kepada Pihak Dinas Sosial Kabupaten Jember UPTD. LIPOSOS Kabupaten Jember yang berkenan bekerjasama dengan Fakultas Kesehatan Masyarakat.

\section{Daftar Pustaka}

[1] Pusat Data dan Informasi Kementerian Kesehatan RI Infodatin 2018. Situasi Kesehatan Jiwa di Indonesia.

[2] Tumanduk.E.M.F., Messakh.T.S., Sukardi.H. 2018. Hubungan Tingkat Kemampuan Perawatan Diri Dengan Tingkat Depresi Pada Pasien Depresi di Bangsal Rumah Sakit Jiwa Daerah Surakarta. Jurnal IImu Kebidanan dan Keperawatan, 9 (1) Undang-Undang Nomor 18 tahun 2014 tentang Kesehatan Jiwa [serial online] http://binfar.kemkes.go.id/?wpdmact=proce ss\&did=MjAxLmhvdGxpbms=[11 Januari 2017].

[3] Moelyaningrum. D. A. 2012. Persepsi Ibu Terhadap Sampah Popok Bayi Sekali Pakai dan Manajemen Pengelolaannya. Open Society Foundation OSF.

[4] Notoatmodjo, S. 2010. Promosi Kesehatan: Teori \& Aplikasi. Jakarta: Rineka Cipta.

[5] Notoatmodjo, Soekidjo. 2007. IImu Kesehatan Masyarakat Prinsip-prinsip Dasar. Jakarta: PT Rineka Cipta.

[6] Gaol M.L. 2017. Life Cycle Assessment (LCA) Pengelolaan Sampah Pada Tempat Pemrosesan Akhir (TPA) Sampah (Studi Kasus: Tpa Jabon, Kabupaten Sidoarjo). Thesis. Surabaya: Fakultas Teknik Sipil dan Perencanaan Institut Teknologi Sepuluh Nopember.

[7] Ali. N., M.R Taib, N.P Soon, O Hassan. 2017. Issues and Management for Used Disposable Diapers In Solid Waste In The City Of Kuala Lumpur. Perintis. 7(1): 43-58. 